\title{
SOME EFFECTS OF MAGNESIUM LOADING UPON RENAL EXCRETION OF MAGNESIUM AND CERTAIN OTHER ELECTROLYTES ${ }^{1}$
}

\author{
By LEON C. CHESLEY AND IRA TEPPER
}

(From the Department of Obstetrics and Gynecology, State University of New York, College of Medicine at New York City, and the Kings County Hospital, Brooklyn, N. Y.)

(Submitted for publication March 19, 1958; accepted June 19, 1958)

Mendel and Benedict (1) injected magnesium salts into animals and found that nearly all of the magnesium could be recovered in the urine. Incidentally, they noted that magnesium injections were followed by "a noteworthy rise in the urinary output of calcium." Schwartz, Smith and Winkler (2) made some measurements of the magnesium clearance in their study of the renal excretion of sulfate by dogs. They found that the renal clearance of magnesium was always less than that of sulfate and, therefore, "presumably the excretion of a small amount of some other cation was stimulated, in order to ensure continuous electroneutrality of urine." Chloride excretion was "almost completely repressed by sulfate excretion." In control periods, in three dogs, the renal clearances of magnesium were 2,1 and $2 \mathrm{ml}$. per minute. Following the injection of magnesium sulfate, in five dogs, the magnesium clearances ranged from 12 to $24 \mathrm{ml}$. per minute with magnesium to creatinine clearance ratios ranging from 0.293 to 0.45 .

Several investigators (3-6) have since found that the magnesium clearance increases after the injection of magnesium salts, although what appears to be the only study systematically relating clearances to plasma concentrations of magnesium has been published only in abstract form $(7,8)$.

Magnesium clearances, which usually have been calculated as $\mathrm{U}_{\mathbf{M g}} \mathrm{V} / \mathrm{P}_{\mathbf{M g}}$, are not a simple reflection of how the kidney handles this element. Copeland and Sunderman (9), as well as others whose work they review, have shown that a third or more of the plasma magnesium is bound to proteins and therefore not filtrable at the glomerulus. Willis and Sunderman (10) have published nomograms from which filtrable magnesium and magnesium concentrations in ultrafiltrates of se-

\footnotetext{
1 Supported by Research Grant H-1837 from the National Institutes of Health, Public Health Service.
}

rum may be derived from the total magnesium and protein concentrations in serum.

The present paper extends the observations reported by others by studying the effects of magnesium over a wider range of serum concentrations, over rising, constant and falling serum levels, and in subjects whose glomerular filtration rates ranged from 25 to $196 \mathrm{ml}$. per minute.

\section{MATERIAL AND METHODS}

Thirty-four women served as subjects of the study. None of the five nonpregnant women had any discernible disturbance in hydration or cardiovascular-renal function. The remaining 29 women were selected with a view to getting cases with a wide range of inulin clearances, with representatives throughout the range. These women were all pregnant and were distributed as follows: "normal", 4 ; preeclampsia, .14; hypertensive disease, 7 ; renal disease, thought to be chronic glomerulonephritis, 4. The patients with renal disease all had hypertension, proteinuria and renal impairment. The one who did not have edema, and who had not been seen here in a previous pregnancy, was in uremia and had a urea clearance of $3 \mathrm{ml}$. per minute. Another had a urea clearance of $30 \mathrm{ml}$. per minute and the remaining two had inulin clearances of 25 and $52 \mathrm{ml}$. per minute, respectively.

All patients were on an 1,800 calorie diet, which contained about $30 \mathrm{mEq}$. of sodium and $90 \mathrm{mEq}$. of potassium. However, some had been in the hospital for only a day or two while others had been in for as long as 29 days before the tests were done.

Two salts of magnesium were used, the sulfate and the acetate.

Procedures (a). In the six experiments with magnesium acetate, the fasting subjects were hydrated with oral water in the early morning. At about 9 a.m. a multiple-eyed catheter was placed in the bladder and an infusion of dilute inulin and sodium para-aminohippurate $(\mathrm{PAH})$ in 0.9 per cent saline was started. The concentrations of inulin and $\mathrm{PAH}$ depended upon the anticipated levels of the clearances of these substances. Priming doses of $3 \mathrm{Gm}$. of inulin in 10 per cent solution and $0.2 \mathrm{Gm}$. of $\mathrm{PAH}$ in 20 per cent solution were injected through the infusion tubing. The infusion was given at the rate of $3.7 \mathrm{ml}$. per minute, using a Bow- 
man pump. After allowing 45 minutes for equilibration, three control clearance periods were run for inulin, PAH and magnesium and for the urinary excretion rates of sodium, potassium, calcium and chloride. As soon as the last control urine had been taken, $100 \mathrm{ml}$. of 10 per cent magnesium acetate $[93.2 \mathrm{mEq}$. of magnesium in $\mathrm{Mg}\left(\mathrm{C}_{2} \mathrm{H}_{3} \mathrm{O}_{2}\right)_{2} \cdot 4 \mathrm{H}_{2} \mathrm{O}$ ] were added to the $350 \mathrm{ml}$. (circa) of remaining infusion solution and the blood and urine collections were continued at intervals of 15 to 30 minutes until all of the infusion solution had been given. The rate of magnesium infusion was about $0.8 \mathrm{mEq}$. per minute.

Venous blood samples were taken midway between urine collections and allowed to clot. At each urine collection, the bladder was washed out with $20 \mathrm{ml}$. of distilled water and blown out with $50 \mathrm{cc}$. of air. The patients lay on their backs, in low Fowler's position, throughout the tests.

In the experiments with magnesium sulfate, several variations were tried.

(b). After three control periods as above, $2 \mathrm{Gm}$. of magnesium sulfate $(16.2 \mathrm{mEq}$. of magnesium in 10 per cent $\mathrm{MgSO}_{4} \cdot 7 \quad \mathrm{H}_{2} \mathrm{O}$ ) was injected intravenously and enough added to the infusion solution to give about 20 to $30 \mathrm{mEq}$. of magnesium per liter and an infusion rate of 70 to $100 \mu \mathrm{Eq}$. of magnesium per minute. After allowing 30 minutes for equilibration, three more clearance periods were run. Then another $2 \mathrm{Gm}$. of magnesium sulfate was given intravenously and the sustaining solution brought to about $41 \mathrm{mEq}$. per liter, giving an infusion rate of $0.15 \mathrm{mEq}$. of magnesium per minute. Again, 30 minutes was allowed for equilibration and then three more clearance periods were run. Three patients were studied in this way, each at three plateaus of serum magnesium concentration. The total dose of magnesium sulfate, as $\mathrm{MgSO}_{4} \cdot 7 \mathrm{H}_{2} \mathrm{O}$, amounted to about $6.5 \mathrm{Gm}$. over a period of about three hours.

(c). After three control periods as above, $10 \mathrm{Gm}$. of magnesium sulfate ( $81.2 \mathrm{mEq}$. of magnesium) in 50 per cent solution was injected intramuscularly and the observations continued for at least four hours. In this variation the serum magnesium concentrations rose for 90 to 120 minutes, were nearly constant for the next 90 to 120 minutes, then fell off. Seven patients had concurrent measurements of inulin and PAH clearances and 12 others did not.

$(d)$. In six patients the serum concentrations of magnesium were raised markedly and acutely and then held nearly constant for three to four hours by injecting almost simultaneously $3 \mathrm{Gm}$. of magnesium sulfate intravenously and $10 \mathrm{Gm}$. intramuscularly (total of 105.5 $\mathrm{mEq}$. magnesium). Inulin and $\mathrm{PAH}$ clearances were not done in this group.

Complete protocols for representative experiments are shown in Table I.

Magnesium was measured in duplicate in serum and urine by the method of Simonsen, Westover and Wertman (11); it was often necessary to dilute the urine samples, by as much as twentyfold after large doses of mag- nesium. Inulin was measured in duplicate or quadruplicate by the method of Roe, Epstein and Goldstein (12). Urinary chlorides were titrated by the method of Volhard and Harvey (13). Sodium and potassium were measured with a Perkin-Elmer 52C flame photometer, using an internal lithium standard. Calcium was measured in duplicate by the method of Tisdall and Kramer (13).

The magnesium clearances, as presented, are approximations because the plasma levels of magnesium were changing during many of the observations. The expression "serum magnesium" will be used henceforth, for this is what was measured. In some contexts, this expression will be equated with plasma magnesium. "Corrected" magnesium clearances are those calculated from the filtrable magnesium, as derived from the nomogram of Willis and Sunderman (10). Whether or not their nomograms can be used legitimately will be taken up in the Discussion.

\section{RESULTS}

\section{Effect of parenteral magnesium upon urine flow and clearances of inulin and $P A H$}

As may be seen in the last two columns of Table II, there was no consistent effect of magnesium upon the rate of urine flow or upon the clearances of inulin and PAH. The fluid intake was constant at $3.7 \mathrm{ml}$. per minute, by infusion. No comparison of the acetate and sulfate salts was attempted, because there are too few cases. The first three of the four procedures described in the Methods section are represented in the table but were not analyzed separately, again because the cases are so few. Data are shown only for the first four (sometimes three) clearance periods in order to average the same number of observations for each period.

Considering all cases together, the average changes were small. This has been the finding of previous investigators. For instance, Heller, Hammarsten and Stutzman (3), who gave magnesium sulfate to six normal young men, found an average decrease of 9.9 per cent in the PAH clearance and an average decrease of 8 per cent in the inulin clearance. Womersley (4) found no effect of magnesium sulfate upon the inulin clearance in five normal men. Etteldorf, Clayton, Tuttle and Houck (14) loaded 15 normal children with magnesium sulfate and found, .. significant changes in either PAH or inulis clearances. Pritchard (15) found no significant effect upon these clearances in seven women with preeclamp- 
TABLE I

Representative experiments on renal effects of magnesium loading

\begin{tabular}{|c|c|c|c|c|c|c|c|c|c|c|c|}
\hline \multirow[b]{2}{*}{ Subject } & \multirow[b]{2}{*}{ Time } & \multirow{2}{*}{$\begin{array}{l}\text { Urine } \\
\text { flow }\end{array}$} & \multirow{2}{*}{$\begin{array}{c}\text { Inulin } \\
\text { clearance }\end{array}$} & \multirow{2}{*}{$\begin{array}{c}\text { PAH } \\
\text { clearance }\end{array}$} & \multirow{2}{*}{$\underset{\mathbf{M g}}{\text { Serum }}$} & \multicolumn{5}{|c|}{ Excretions $(\mu E q . / m i n)}$. & \multirow{2}{*}{$\begin{array}{c}\mathbf{M g} \\
\text { clearance }\end{array}$} \\
\hline & & & & & & $\mathrm{Na}$ & $\mathrm{Cl}$ & $\mathbf{K}$ & $\mathbf{C a}$ & $\mathbf{M g}$ & \\
\hline \multirow[t]{4}{*}{$1^{*}$} & $\begin{array}{c}\min . \\
0 \\
\text { Mean of } \\
3\end{array}$ & $\begin{array}{l}\text { ml./min. } \\
\text { Prime: } \\
\text { Sustain }\end{array}$ & $\begin{array}{l}\text { ml. } / \min . \\
\text { Inulin, } 3 \\
\mathrm{gg} \text { infusio }\end{array}$ & $\begin{array}{l}\text { ml./min. } \\
\text { m. and P } \\
\text { A: Inuli } \\
\text { at } 3.7\end{array}$ & $\begin{array}{l}m E q . / L . \\
\mathrm{H}, 0.4 \mathrm{Gm} . \\
88 \mathrm{mg} . / \mathrm{min} . \\
\mathrm{nl} . / \mathrm{min} .\end{array}$ & ad $P$ & $\mathrm{H}, 31$. & mg./ & ain. in & $0.9 \% \mathrm{~N}$ & $\begin{array}{l}\text { ml./min. } \\
\text { olution }\end{array}$ \\
\hline & $45-102$ & 9.89 & 141 & 684 & 1.58 & 327 & 367 & 105 & 3.3 & 9.0 & 5.7 \\
\hline & 103 & \multicolumn{10}{|c|}{ Sustaining infusion: $93.2 \mathrm{mEq} . \mathrm{Mg}$ in $10 \% \mathrm{Mg}\left(\mathrm{C}_{2} \mathrm{H}_{3} \mathrm{O}_{2}\right)_{2} \cdot 4 \mathrm{H}_{2} \mathrm{O}$ solution added to $\mathrm{A}$} \\
\hline & $\begin{array}{l}102-123 \\
123-144 \\
144-162 \\
162-184 \\
184-204\end{array}$ & $\begin{array}{l}10.29 \\
12.57 \\
11.33 \\
10.63 \\
13.20\end{array}$ & $\begin{array}{l}153 \\
174 \\
169 \\
173 \\
184\end{array}$ & $\begin{array}{l}727 \\
724 \\
706 \\
750 \\
744\end{array}$ & $\begin{array}{l}1.79 \\
2.64 \\
2.92 \\
3.64 \\
4.03\end{array}$ & $\begin{array}{l}322 \\
404 \\
468 \\
534 \\
454\end{array}$ & $\begin{array}{l}364 \\
490 \\
481 \\
546 \\
722\end{array}$ & $\begin{array}{r}106 \\
89 \\
77 \\
80 \\
89\end{array}$ & $\begin{array}{r}3.6 \\
12.9 \\
17.5 \\
21.6 \\
30.1\end{array}$ & $\begin{array}{r}15.2 \\
84.3 \\
113.0 \\
180.0 \\
237.0\end{array}$ & $\begin{array}{l}8.5 \\
31.9 \\
38.7 \\
49.5 \\
58.8\end{array}$ \\
\hline
\end{tabular}

$2 \dagger$

0
Mean of
3 controls 45-88

90

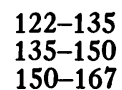

150-167

170

200-211

211-224

224-238

$3 t$

0

Mean of 3
controls

48-104

104-127

127-148

148-172

172-194

195

194-222

222-244

$4 \|$

Mean of 3
controls

0-118

118-125

137-192

192-252

252-312

312-376

377-380

376-437

Prime: Inulin, $3 \mathrm{Gm}$. and PAH, $0.4 \mathrm{Gm}$.

Sustaining infusion A: Inulin, $53 \mathrm{mg} . / \mathrm{min}$. and $\mathrm{PAH}, 21 \mathrm{mg} . / \mathrm{min}$. in $0.9 \% \mathrm{NaCl}$ solution at $3.7 \mathrm{ml} . / \mathrm{min}$.

$\begin{array}{lllllllll}5.66 & 60 & 421 & 1.83 & 234 & 164 & 60 & 3.3 & 3.3\end{array}$

Prime: $16.2 \mathrm{mEq}$. $\mathrm{Mg}$ in $10 \% \mathrm{MgSO}_{4} \cdot 7 \mathrm{H}_{2} \mathrm{O}$ solution

Sustaining infusion B: $5.7 \mathrm{mEq}$. Mg in $10 \% \mathrm{MgSO}_{4} \cdot 7 \mathrm{H}_{2} \mathrm{O}$ solution added to A

$\begin{array}{llllllllll}5.08 & 55 & 414 & 3.12 & 237 & 139 & 33 & 11.2 & 27.1 & 8.7 \\ 4.80 & 48 & 345 & 3.26 & 260 & 140 & 29 & 12.4 & 31.6 & 9.7 \\ 4.70 & 43 & 306 & 3.38 & 254 & 161 & 30 & 14.0 & 30.8 & 9.1\end{array}$

Prime: $16.2 \mathrm{mEq} . \mathrm{Mg}$ in $10 \% \mathrm{MgSO}_{4} \cdot 7 \mathrm{H}_{2} \mathrm{O}$ solution

Sustaining infusion C: $16.2 \mathrm{mEq}$. $\mathrm{Mg}$ in $10 \% \mathrm{MgSO}_{4} \cdot 7 \mathrm{H}_{2} \mathrm{O}$ solution added to $400 \mathrm{ml}$. of A

$\begin{array}{llllllllll}5.45 & 47 & 311 & 4.82 & 327 & 233 & 30 & 27.7 & 78.6 & 16.3 \\ 4.47 & 44 & 286 & 4.50 & 289 & 192 & 26 & 24.1 & 64.8 & 14.4 \\ 4.29 & 46 & 292 & 4.64 & 302 & 205 & 29 & 24.7 & 62.2 & 13.4\end{array}$

Prime: Inulin, $3 \mathrm{Gm}$.

Sustaining infusion: Inulin, $88 \mathrm{mg} . / \mathrm{min}$. in $0.9 \% \mathrm{NaCl}$ solution at $3.7 \mathrm{ml} . / \mathrm{min}$.

$\begin{array}{llllllll}5.06 & 121 & 1.68 & 47 & 48 & 16 & 3.8 & 5.7\end{array}$

$81.2 \mathrm{mEq} . \mathrm{Mg}$ in $50 \% \mathrm{MgSO}_{4} \cdot 7 \mathrm{H}_{2} \mathrm{O}$ solution, intramuscularly

$\begin{array}{lrlrrrrrr}4.17 & 107 & 2.02 \S & 79 \S & 64 \S & 14 & 12.7 \S & 19.6 & 9.7 \S \\ 4.00 & 115 & 2.71 & 97 & 110 & 19 & 16.4 & 46.3 & 17.1 \\ 3.08 & 99 & 3.26 & 99 & 111 & 18 & 36.4 & 139.5 & 42.8 \\ 3.37 & 103 & 3.75 & 108 & 115 & 19 & 42.1 & 172.0 & 45.9\end{array}$

$40.6 \mathrm{mEq} . \mathrm{Mg}$ in $50 \% \mathrm{MgSO}_{4} \cdot 7 \mathrm{H}_{2} \mathrm{O}$ solution, intramuscularly

$\begin{array}{lrlllllll}2.43 & 96 & 4.47 & 133 & 102 & 19 & 46.6 & 215.5 & 48.2 \\ 2.41 & 107 & 5.00 & 152 & 136 & 21 & 64.4 & 317.5 & 63.5\end{array}$
1.92
1.69
$\begin{array}{lll}74 & 44 & 13\end{array}$
1.1
6.1
3.6

$24.3 \mathrm{mEq} . \mathrm{Mg}$ in $10 \% \mathrm{MgSO}_{4} \cdot 7 \mathrm{H}_{2} \mathrm{O}$ solution intravenously, plus $81.2 \mathrm{mEq}$. $\mathrm{Mg}$ in $50 \%$ $\mathrm{MgSO}_{4} \cdot 7 \mathrm{H}_{2} \mathrm{O}$ solution intramuscularly

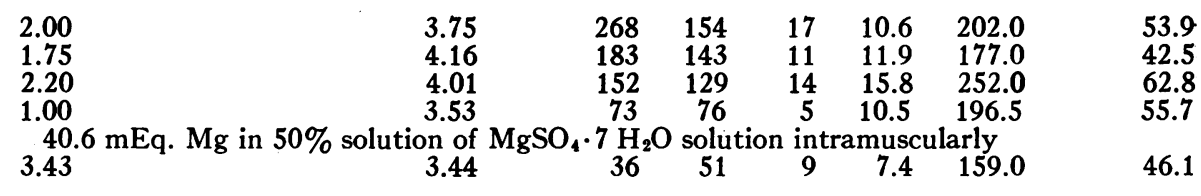

* Case of essential hypertension in the thirty-ninth week of gestation. Procedure (a), described in section on methods.

$\dagger$ Case of essential hypertension in the thirty-second week of gestation. Procedure $(b)$, described in section on methods.

† Nonpregnant "normal" patient. Procedure (c).

Not used because of uncertainty as to mean serum magnesium concentration in this period.

Case of severe preeclampsia in the thirty-sixth week of gestation. Procedure $(d)$. 
TABLE II

Rates of urine flow $(V)$, inulin clearance $\left(C_{I}\right)$ and para-aminohippurate clearance $\left(C_{P A H}\right)$ during and after injection of magnesium salts

\begin{tabular}{|c|c|c|c|c|c|c|c|c|}
\hline \multirow[b]{2}{*}{ Group } & \multirow[b]{2}{*}{ Cases } & \multirow[b]{2}{*}{ Control } & \multicolumn{4}{|c|}{ Periods during or after $\mathbf{M g}$ injection } & \multicolumn{2}{|c|}{ Periods with } \\
\hline & & & 1 & 2 & 3 & 4 & Increase $†$ & Decrease $\dagger$ \\
\hline \multicolumn{9}{|l|}{ Normal } \\
\hline $\begin{array}{l}\mathrm{V} \\
\mathrm{C}_{\mathrm{I}} \\
\mathrm{C}_{\mathrm{PAH}}\end{array}$ & $\begin{array}{l}5^{*} \\
5^{*} \\
1^{*}\end{array}$ & $\begin{array}{l}4.84 \\
127 \\
689\end{array}$ & $\begin{array}{l}4.06 \\
108 \\
770\end{array}$ & $\begin{array}{l}3.97 \\
107 \\
602\end{array}$ & $\begin{array}{l}3.94 \\
110 \\
796\end{array}$ & 118 & $\begin{array}{r}25.0 \\
5.0 \\
66.7\end{array}$ & $\begin{array}{l}75.0 \\
40.0 \\
33.3\end{array}$ \\
\hline \multicolumn{9}{|c|}{ Preeclampsia } \\
\hline $\begin{array}{l}\mathrm{V} \\
\mathrm{C}_{\mathrm{I}} \\
\mathrm{C}_{\mathrm{PAH}}\end{array}$ & $\begin{array}{l}4 \\
4 \\
4\end{array}$ & $\begin{array}{c}3.85 \\
98 \\
422\end{array}$ & $\begin{array}{l}3.85 \\
103 \\
418\end{array}$ & $\begin{array}{l}3^{3.14} \\
124 \\
351\end{array}$ & $\begin{array}{l}3.77 \\
115 \\
417\end{array}$ & $110^{3.82}$ & $\begin{array}{l}37.5 \\
31.2 \\
50.0\end{array}$ & $\begin{array}{r}56.3 \\
37.5 \\
8.3\end{array}$ \\
\hline \multicolumn{9}{|c|}{ Hypertension } \\
\hline $\begin{array}{l}\mathrm{V} \\
\mathrm{C}_{\mathrm{I}} \\
\mathrm{C}_{\mathrm{PAB}}\end{array}$ & $\begin{array}{l}5 \\
5 \\
5\end{array}$ & $\begin{array}{c}5.32 \\
89 \\
357\end{array}$ & $\begin{array}{l}5.05 \\
86 \\
373\end{array}$ & $\begin{array}{c}9.73 \\
552\end{array}$ & $\begin{array}{c}6.33 \\
90 \\
485\end{array}$ & $\begin{array}{c}5.62 \\
86 \\
517\end{array}$ & $\begin{array}{l}25.0 \\
15.0 \\
10.0\end{array}$ & $\begin{array}{l}20.0 \\
25.0 \\
15.0\end{array}$ \\
\hline \multicolumn{9}{|c|}{ Renal Disease } \\
\hline $\begin{array}{l}\mathrm{V} \\
\mathrm{C}_{\mathrm{I}} \\
\mathrm{C}_{\mathrm{PAH}}\end{array}$ & $\begin{array}{l}2 \\
2 \\
2\end{array}$ & $\begin{array}{c}1.21 \\
40 \\
260\end{array}$ & $\begin{array}{c}1.34 \\
56 \\
348\end{array}$ & $\begin{array}{c}1.31 \\
51\end{array}$ & $\begin{array}{c}5^{1.43} \\
280\end{array}$ & 2.33 & $\begin{array}{l}62.5 \\
50.0 \\
33.3\end{array}$ & $\begin{array}{l}25.0 \\
50.0 \\
33.3\end{array}$ \\
\hline \multicolumn{9}{|l|}{ Totals } \\
\hline $\begin{array}{l}\mathrm{V} \\
\mathrm{C}_{\mathrm{I}} \\
\mathrm{C}_{\mathrm{PAH}}\end{array}$ & $\begin{array}{l}16 \\
16 \\
12\end{array}$ & $\begin{array}{c}4.29 \\
98 \\
390\end{array}$ & $\begin{array}{l}3.97 \\
94 \\
417\end{array}$ & $\begin{array}{l}3.98 \\
100 \\
444\end{array}$ & $\begin{array}{c}4.33 \\
98 \\
454\end{array}$ & 4.39 & $\begin{array}{l}32.8 \\
19.4 \\
29.3\end{array}$ & $\begin{array}{l}46.9 \\
35.4 \\
17.1\end{array}$ \\
\hline
\end{tabular}

* One normal pregnancy.

$\dagger$ Changes greater than 10 per cent.

sia, who were given 4 to $6 \mathrm{Gm}$. of magnesium sulfate intravenously.

\section{Effect of magnesium upon the uncorrected mag- nesium clearance}

The relationship between the total serum magnesium and the uncorrected renal clearance of magnesium is shown in Figure 1. The eight patients represented here were selected as "normals" in that they gave no evidence of disturbance in hydration or cardiovascular or renal function. There was a roughly linear increase in the magnesium clearance with rising serum concentrations of magnesium, both when magnesium sulfate and when magnesium acetate were given.

Figure 2 shows the same relationship in patients selected for a wide range in the inulin clearance. One woman in the terminal stage of glomerulonephritis and azotemia, with a urea clearance of 3 ml. per minute (inulin clearance not measured), had only a slight increase in the magnesium clearance (from 1.2 to $2.8 \mathrm{ml}$. per minute) when the serum concentration was increased from 2.1 to $4.4 \mathrm{mEq}$. per liter. At each level of glomerular filtration, the magnesium clearance increased as a linear function of the serum magnesium concentration (roughly, as in Figure 1).

\section{Ratio of "corrected" magnesium clearance to inulin clearance}

The data shown in Figure 3 are from 16 patients in whom inulin and magnesium clearances were measured simultaneously. These patients were selected to cover a wide range of inulin clearances, which, in the control periods, varied from 25 to $196 \mathrm{ml}$. per minute. The "corrected" magnesium clearances, therefore, varied widely. However, calculation of the ratio of the corrected magnesium clearance to the inulin clearance brought these data to a common base and Figure 3 indicates that the effects of the two magnesium salts were about the same, that is, the serum magnesium concentration rather than the attendant anion seems to determine the renal excretion of magnesium. It 


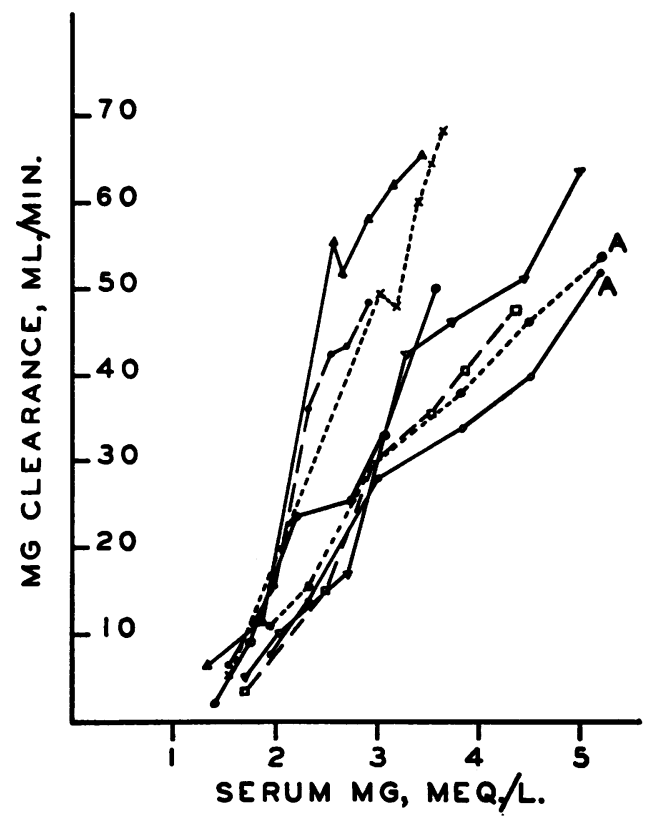

Fig. 1. The Relationship Between the Magnesium Clearance, Uncorrected for Protein Binding of Serum Magnesium, and the Serum Concentration of Total Magnesium

Eight "normal" subjects. A denotes subjects given magnesium acetate [Procedure $(a)$ ]; the others were given magnesium sulfate [Procedure $(c)$ ].

also shows that the moderately impaired kidney handled magnesium as did the normal one-that is, the tubular reabsorption or rejection of magnesium per $100 \mathrm{ml}$. of glomerular filtrate was similar from patient to patient. The triangles in Figure 3 denote observations in patients with glomerulonephritis and inulin clearances of less than $60 \mathrm{ml}$. per minute.

At the serum concentrations of magnesium studied, the clearance ratio of "filtrable" magnesium to inulin rose steeply as the serum concentration of magnesium increased. The clearance ratio approached but did not reach 1 . This suggested the possibility that tubular reabsorption of magnesium might have been nearly maximal under "basal" conditions and that increments in the filtered load were excreted almost completely. Figure 4 indicates that this may have been so in 13 of the 16 patients studied. The filtered load was calculated by multiplying the inulin clearance by the concentration of magnesium in ultrafiltrate, as derived from the appropriate nomogram of Willis and Sunderman (10). In Figure 4, the increases in magnesium excretion over control values do seem to bear a 1 to 1 ratio to the increments in the calculated filtered loads, for most of the points fall close to the line describing such a relationship. Three abnormal patients (one with essential hypertension and two with preeclampsia) deviated widely from the general pattern, in that all observations fell far below the line. These patients are indicated in the graph by the broker lines connecting their points.

\section{Tubular reabsorption of magnesium}

If the nomogram of Willis and Sunderman (10) can be used legitimately for the derivation of magnesium concentrations in ultrafiltrates of plasma, Figure 4 describes the tubular reabsorption of magnesium. Points falling above the line would represent decreases in tubular reabsorption under

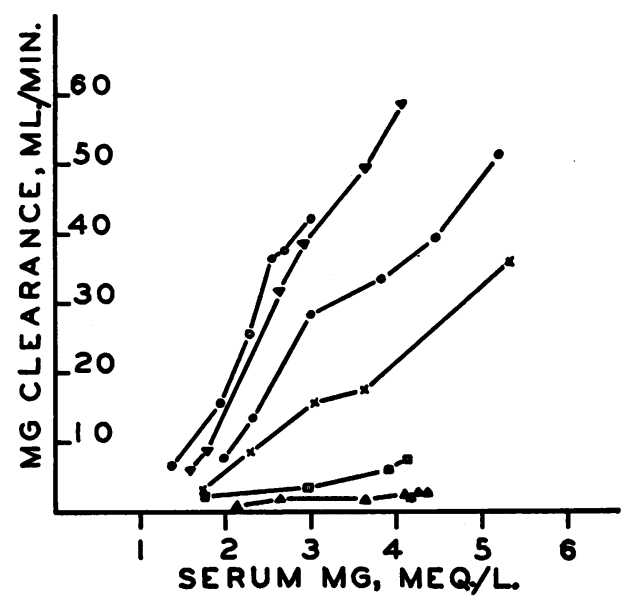

Fig. 2. The Relationship Between the Uncorrected Renal Clearance of Magnesium and the Serum Concentration of Magnesium at Various Levels of Glomerular Filtration

Reading down from the top, the lines are as follows: $\mathrm{O}-$ inulin clearance, $196 \mathrm{ml}$. per minute. Nonpregnant "normal" subject given intramuscular magnesium sulfate [Procedure (c) ]. $\nabla$-inulin clearance, $150 \mathrm{ml}$. per minute. Pregnant hypertensive patient given magnesium acetate infusion [Procedure $(a)$ ]. - -inulin clearance, $88 \mathrm{ml}$. per minute. Nonpregnant "normal" subject given magnesium acetate infusion [Procedure $(a)$ ]. $\times$-inulin clearance, $57 \mathrm{ml}$. per minute. Pregnant hypertensive patient given magnesium acetate infusion [Procedure (a) ]. $\square$-inulin clearance, $25 \mathrm{ml}$. per minute. Pregnant patient with glomerulonephritis given constant infusions of magnesium sulfate [Procedure (b)]. $\triangle-$ pregnant patient in uremia. Inulin clearance not measured; urea clearance, $3 \mathrm{ml}$. per minute. 


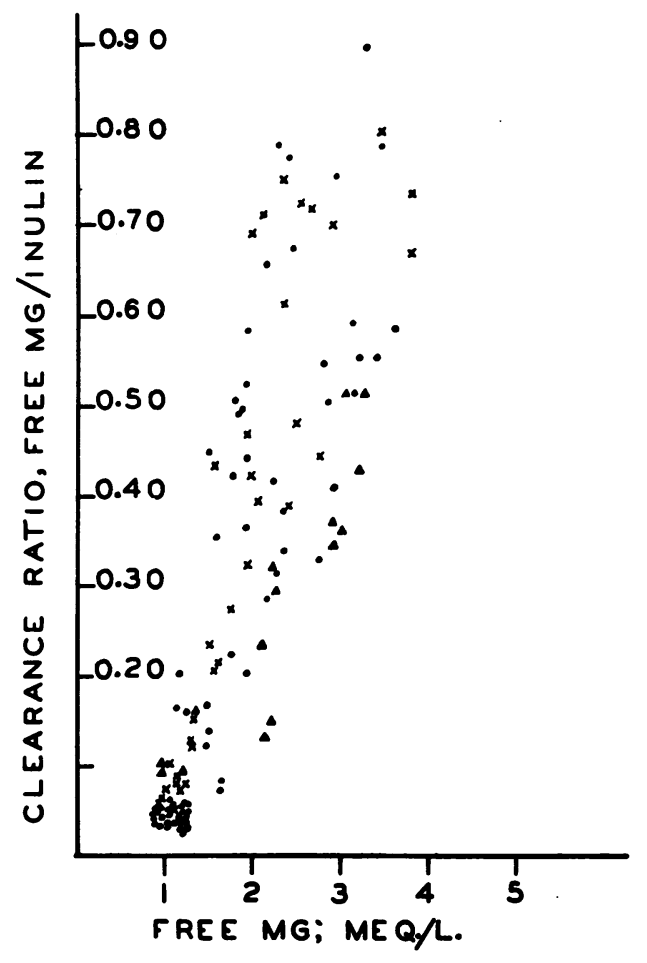

Fig. 3. The Relationship Between the Clearance Ratio of "Filtrable" Magnesium to InUlin and the Serum Concentration of "Filtrable" Magnesium

The inulin clearances ranged from 25 to $196 \mathrm{ml}$. per minute. $\bullet$ magnesium sulfate; $\times$, magnesium acetate; $\triangle$, patients with glomerulonephritis.

higher filtered loads, while points below the line would represent increased tubular reabsorption. Except for the three abnormal cases, most of the points fall close enough to the line to suggest that the tubular reabsorption of magnesium was nearly constant over the range of filtered loads studied and that reabsorption was nearly maximal under "basal" conditions. When the control load was increased by less than $50 \mu \mathrm{Eq}$. per minute, most of the points fell below the line. This would suggest that the tubular reabsorptive mechanism was not quite saturated before magnesium was injected. ${ }^{2}$

2 In 43 observations the increments in filtered load exceeded $50 \mu \mathrm{Eq}$. per minute. The line fitted to these points by the method of least squares had its intercept at -6 , $\mathrm{S}_{\mathrm{a}}=12.44$; this is not significantly different from a zero intercept $(t=0.483, p>0.5)$. The slope of the line was $1.031, S_{b}=0.086$; this is not significantly different from a slope of $1(t=0.36, p>0.5)$. Similarly, a line was fitted to the 23 points representing increments of less
In the three aberrant cases the tubular reabsorption appears to have increased when the filtered load increased. In one of these, a preeclamptic, the control inulin clearance of $86 \mathrm{ml}$. per minute nearly doubled and became variable after magnesium sulfate was injected. In the other two the inulin clearance varied but little from the control values of $110 \mathrm{ml}$. per minute in the patient with preeclampsia and $170 \mathrm{ml}$. per minute in the one with essential hypertension.

\section{Effect of magnesium administration upon calcium excretion}

The usual effect of magnesium injection was to increase the urinary excretion of calcium. Roughly, the calcium excretion increased as the serum concentration of magnesium rose, as Fig-

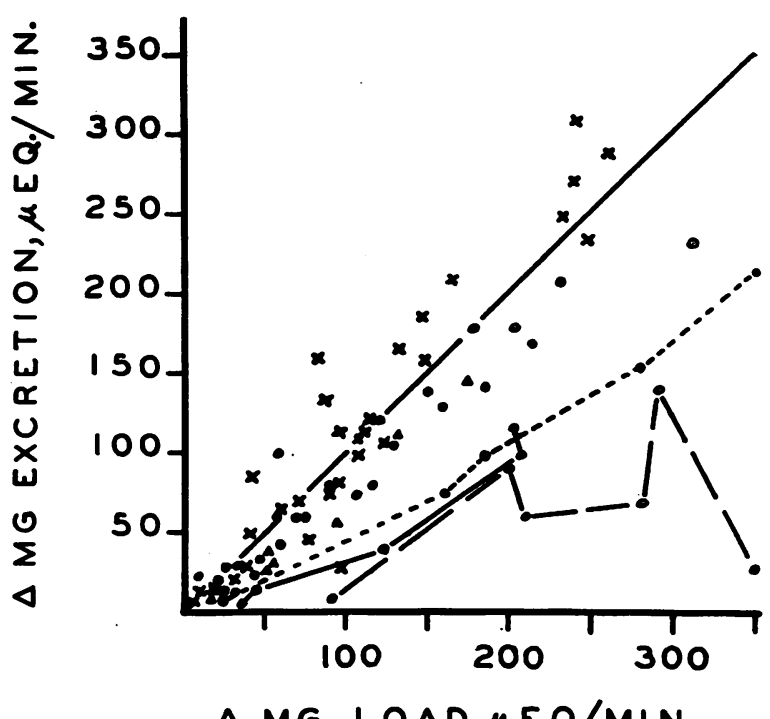

$\triangle M G L O A D, \mu E Q / M I N$.

Fig. 4. The Relationship Between Increments in Magnesium Excretion and InCREments in the FiLTERED LOAD OF MAGNESIUM

The points connected by the broken lines indicate observations in three abnormal and atypical patients. $X$, normal; $\bullet$, hypertension; $\Delta$, renal disease; $O$, preeclampsia.

than $50 \mu \mathrm{Eq}$. per minute in the filtered load. Its intercept was $+7, S_{\mathrm{a}}=5.4$, not significantly different from $0(\mathrm{t}=1.3, \mathrm{p}=0.2)$. The slope was $0.414, \mathrm{~S}_{\mathrm{b}}=0.2$. This is significantly different from $1(t=2.93, p<0.01)$. Therefore the points for increments of less than $50 \mu \mathrm{Eq}$. per minute do fall significantly below the line shown in the graph. The three aberrant cases have been excluded from this analysis. 
ure 5 shows. Only seven observations were made at serum magnesium concentrations greater than $5 \mathrm{mEq}$. per liter and the average drop shown for calcium excretion at these high levels of serum magnesium probably is not real, for it was not seen in individual cases. The increases in calcium excretion following magnesium acetate were comparable to those following magnesium sulfate injections.

Calcium excretion was measured in 29 patients. Only 2 failed to show increased urinary loss of calcium after the injection of a magnesium salt. One of these had an inulin clearance of $25 \mathrm{ml}$. per minute (glomerulonephritis) and the other, with mild preeclampsia, had an inulin clearance of 110 ml. per minute. The calcium excretion in any 1 patient, other than these 2 , was always maximal when the serum magnesium was at its highest level. In 12 cases, observations were made while the serum magnesium concentration first rose and later declined. In every such instance the calcium excretion decreased from its peak as the serum magnesium fell.

\section{Effect of magnesium administration upon sodium and chloride excretions}

Both magnesium acetate and magnesium sulfate injections increased the sodium and chloride excretions (Figure 5). Twenty-nine patients were studied in 100 clearance periods following magnesium injections. Sodium and chloride excretions were almost equimolar and the coefficient of correlation ( $r$ ) between them was 0.80 . The stimulation of sodium and chloride excretions seemed to depend upon a rising serum concentration of magnesium, for whenever the serum magnesium became nearly constant or fell the excretions dropped back toward, to, or below the control levels. Only one patient failed to show an augmentation in sodium and chloride excretion while the serum magnesium was rising; she had essential hypertension and in the control periods had high excretions (chloride, $760 \mu \mathrm{Eq}$. and sodium, $722 \mu$ Eq. per minute). Following the intramuscular injection of magnesium sulfate, the excretions fell to about one-third of the control values.

Figure 6 shows what happened to sodium and chloride excretions when the serum magnesium rose, then remained nearly constant, and then fell.

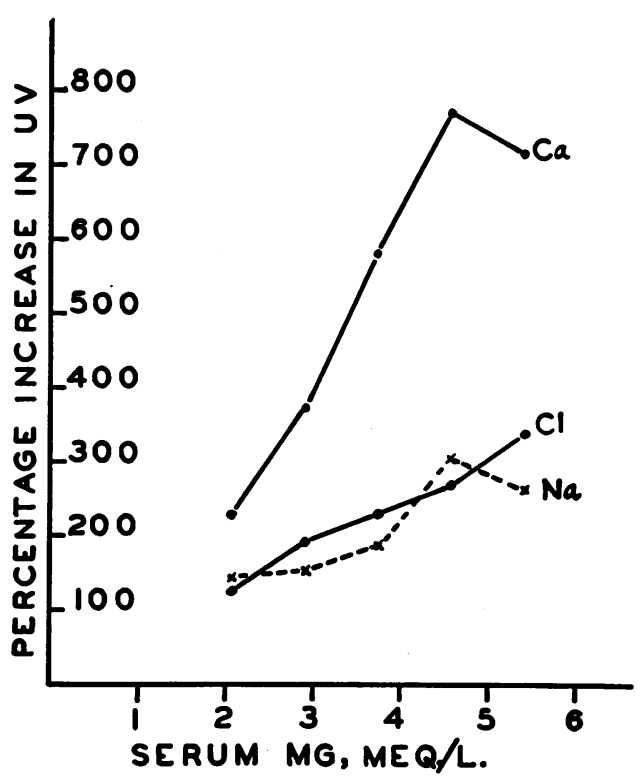

Fig. 5. The Stimulation of Calcium, Sodium and Chloride Excretions and their Dependence upoN Serum Concentration of Magnesium

All patients, normal and abnormal, have been pooled.

The lines connect points representing consecutive observations. Sodium and chloride excretions rose sharply while the serum magnesium was increasing, dropped precipitously while the serum magnesium was essentially constant, and fell back toward, to, or below control levels when the serum magnesium began to decline. This was observed in all six cases in which Procedure $(d)$ was used. Six of the patients studied with Procedure $(c)$ had serum magnesium concentrations that became constant or fell during the periods in which sodium and chloride excretions were measured; all showed the same effect. Unfortunately, inulin clearances were not measured in any of these periods and nothing can be said about a possible relationship between changing filtration rates and changes in sodium excretion.

\section{Effect of magnesium administration upon potas- sium excretion}

Four of the six patients infused with magnesium acetate had sustained decreases in potassium excretion during the infusion. The two exceptions both had depressed inulin clearances. One, with glomerulonephritis, had a control inulin clearance of $52 \mathrm{ml}$. per minute and a sustained increase in 
potassium excretion. The other, with long-standing and rather severe essential hypertension, had a control inulin clearance of $57 \mathrm{ml}$. per minute and a sustained increase (of less than 10 per cent) in potassium excretion.

Following the injection, or during the infusion, of magnesium sulfate only 8 of 22 subjects had sustained decreases in potassium excretion. Six had sustained increases and these six patients were represented in the nonpregnant, normal pregnant, preeclamptic and pregnant nephritic groups.

Excluding the two patients with glomerulonephritis, in whom potassium excretions were measured, and averaging all other observations, magnesium sulfate depressed potassium excretion by a mean of 11 per cent, but the excretion was actually increased in 39 per cent of the periods. The mean decrease in potassium excretion during magnesium acetate infusions was 25 per cent and increases were seen in only 2 of 29 periods.

No correlation could be discerned between changes in potassium excretion and the serum concentrations or direction of change in serum concentrations of magnesium.

A relation was sought between changes in sodium excretion and changes in potassium excretion, on the hypothesis that magnesium might interfere with the renal tubular exchange of potassium for sodium. However, no relation was found. When sodium excretion increased, potassium excretion might decrease, increase, or remain at the same level.

\section{DISCUSSION}

The method used for the measurement of serum and urine magnesium concentrations was chosen because it gave us better recoveries of added magnesium than did the titan yellow method. Engbaek (16), citing earlier work of his own, wrote that the preliminary separation of calcium by oxalate precipitation does not interfere with the measurement of magnesium in normal serum. However, ". . . when the serum contains about 10 times the $(\mathrm{Mg})$ value of the normal serum, the separation of calcium results in a loss of 4 to 8 per cent of the total magnesium." This results from the occlusion of magnesium oxalate in the calcium oxalate precipitate. This source of error was partially offset by the preliminary dilution

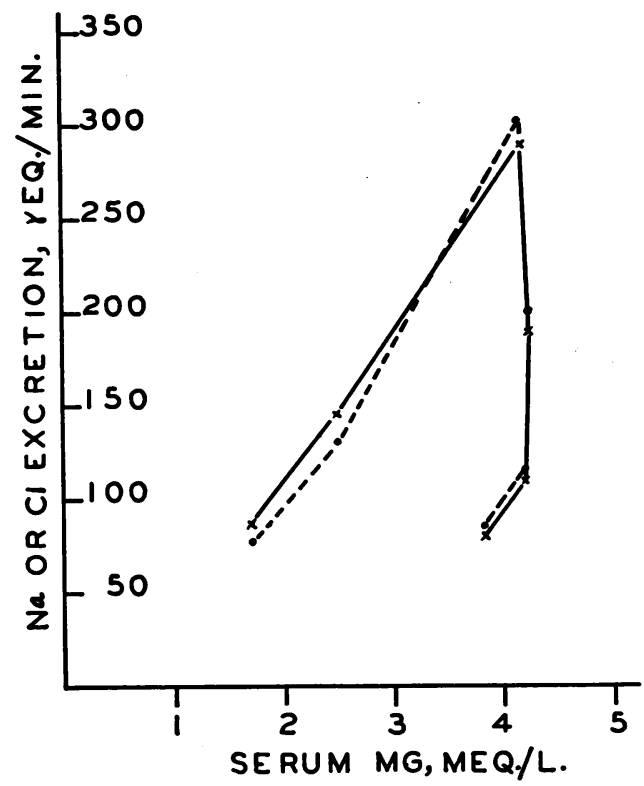

Fig. 6. Sodium and Chloride Excretions Related to the Trend of Serum Magnesium Concentration

The graph shows data for one representative case. The lines connect consecutive observations. Broken line denotes chloride excretion, solid line denotes sodium excretion.

of sera and urines expected to have high concentrations of magnesium.

Although several investigators (1-8) have shown that the renal clearance (or excretion) of magnesium increases after the injection of magnesium salts, no data have been published to show how the renal clearance of magnesium depends upon the serum magnesium concentration. (Barker, Clark and Elkinton (8) have published only an abstract of their systematic work on this.) The published clearance findings are summarized in Table III.

Figures 1, 2 and 3 indicate that the magnesium clearance increases as a roughly linear function of the serum magnesium concentration and that the attendant anion has but little effect. Magnesium acetate was chosen for comparison to the sulfate because the rapid utilization of acetate by the body would remove a large proportion of the anion, which presumably was replaced by bicarbonate. Thus the high clearance rate of such an anion as sulfate would not obligate the excretion of cations such as magnesium and a nearly "pure" effect of magnesium could be studied. Presumably the 
TABLE III

Reported effects of magnesium loading upon renal excretion of magnesium

\begin{tabular}{|c|c|c|c|c|c|c|c|c|}
\hline \multirow[b]{2}{*}{ Author } & \multirow[b]{2}{*}{ Subjects } & \multicolumn{3}{|c|}{ Control observations } & \multirow{2}{*}{$\begin{array}{l}\text { Magnesium } \\
\text { sulfate }\end{array}$} & \multicolumn{3}{|c|}{ After magnesium loading } \\
\hline & & Serum $\mathbf{M g}$ & $\mathrm{C}_{\mathbf{m}_{\mathbf{2}}^{*}}$ & $\mathrm{CM}_{\mathrm{z}} / \mathrm{C}_{\mathrm{I}} *$ & & Serum Mg & $C_{u_{z}}$ & $\mathrm{Cu}_{\boldsymbol{z}} / \mathrm{C}_{\mathbf{I}}$ \\
\hline $\begin{array}{l}\text { Schwartz, Smith } \\
\text { and Winkler (2) }\end{array}$ & 5 dogs & $m E q . / L$ & $\underset{1-2}{m l . / m i n}$ & $\times 100$ & Intravenous & $m E q . / L$ & $\begin{array}{c}\operatorname{ml} . / \min \\
12-24\end{array}$ & $\begin{array}{l}\times 100 \\
29-45 \dagger\end{array}$ \\
\hline $\begin{array}{l}\text { Heller, Hammarsten } \\
\text { and Stutzman (3) }\end{array}$ & 6 men & $1.49-1.73$ & $3.98-6.75$ & $2.9-5.3$ & $\begin{array}{l}1.02 \mathrm{mEq} . / \\
\text { min., I.V. }\end{array}$ & $2.07-2.42$ & $24-32$ & $16-25$ \\
\hline Womersley (4) & 5 men & $1.5-1.9$ & & $2.3-5.6$ & $\begin{array}{l}20 \text { mEq., } \\
\text { I.V. }\end{array}$ & $2.3-2.8$ & & $16-22$ \\
\hline
\end{tabular}

${ }^{*} \mathrm{C}_{\mathrm{Mg}_{\mathrm{g}}}$, uncorrected magnesium clearance; $\mathrm{C}_{\mathrm{I}}$, inulin clearance.

$\dagger \mathrm{C}_{\mathbf{M g}_{\mathrm{g}}} / \mathrm{C}_{\text {Creatinine. }}$

acetate infusions resulted in the production of alkaline urines, which may have affected magnesium (and potassium) excretions.

The derivation of "filtrable" magnesium from the nomogram of Willis and Sunderman (10) assumes that the injected magnesium was promptly bound to plasma proteins to the same degree that slowly accumulated "endogenous" magnesium would be in the steady state. Hopkins, Howard and Eisenberg (17) added magnesium chloride to serum and found that in the range of 2.2 to 26.4 mg. per $100 \mathrm{ml}$. the amount of magnesium bound to proteins rose proportionately to the total serum concentration of magnesium. They found the same to be true for calcium, as did Terepka, Toribara and Dewey (18). Thus, binding sites are available and Copeland and Sunderman (9) found that magnesium proteinate acts as a dissociated salt, following the mass action law with a calculated $\mathrm{pK}$ of 1.77 .

In the magnesium acetate infusion studies, the plasma $\mathrm{pH}$ may have increased somewhat. Possibly this could have affected the proportion of magnesium that was filtrable. Against this possibility is the fact that Hopkins, Howard and Eisenberg (17) found no effect of $\mathrm{pH}$ upon the filtrable fraction of calcium, in the range of $\mathrm{pH}$ 7.26 to 7.47 ; at higher $\mathrm{pH}$ levels, the filtrable fraction decreased. They also studied the effect of $\mathrm{pH}$ on the filtrability of magnesium, in the range of $\mathrm{pH} 7.28$ to 7.46 , and apparently found no effect (although this was not clearly stated so strongly).

In calculating the "corrected" clearances, as well as the filtered loads and tubular reabsorption of magnesium, the validity of the derivation of filtrable magnesium is crucial. If the injected magnesium is not bound to proteins in the same proportion as is the basal serum magnesium, then the derived data underestimate the filtered load and, therefore, the amount of magnesium reabsorbed by the tubules.

Hammarsten, Allgood and Smith (6) found that patients with advanced renal disease and azotemia had abnormally high ratios of "corrected" magnesium clearances to inulin clearances before magnesium was given. The triangles in Figure 3 show that this was true in our three cases of chronic glomerulonephritis with lesser degrees of renal impairment (inulin clearances from 25 to $60 \mathrm{ml}$. per minute). These investigators also noted that the clearance ratio did not increase so much in the nephritic patients after magnesium injection as it did in normal subjects. This is not so clear-cut in Figure 3, perhaps because of the relatively good residual function in our cases. The inulin clearance was not measured in the one patient with azotemia and a urea clearance of $3 \mathrm{ml}$. per minute, but the magnesium clearance increased only slightly after the injection of magnesium sulfate (triangles in Figure 2)-i.e., the clearance ratio probably did not increase by much.

The increase in calcium excretion after the injection of magnesium salts confirms other investigations $(1,4)$ and in addition the present data show a good correlation between the serum concentration of magnesium and the increase in calcium loss; in individual subjects the correlation was almost linear. This was equally true for both rising and falling serum concentrations of magnesium, which is quite different from the 
effect of magnesium upon the excretion of sodium and chloride. The acetate and sulfate salts were equally effective. This means that the calcium excretion was not obligated by sulfate excretion, as might be inferred from the quotation of Schwartz, Smith and Winkler (2) in the introduction. Perhaps the renal tubule cannot differentiate perfectly between calcium and magnesium, which may compete for reabsorption. No explanation is offered for the failure of magnesium to stimulate the excretion of calcium in 2 of the 29 patients studied.

The dependence of the stimulation of sodium and chloride excretions upon a rising concentration of serum magnesium explains the transitory effect noted by Womersley (4) and Pritchard (15), who gave single intravenous injections of magnesium sulfate, and the sustained effect reported by Heller, Hammarsten and Stutzman (3), who gave continuous infusions. Womersley did not find any stimulation of sodium or chloride excretion after magnesium lactate, although magnesium acetate in the present study did have such an effect. This discrepancy and the statement of Schwartz, Smith and Winkler (2) that magnesium sulfate injections almost completely repressed the excretion of chloride remain unresolved. Womersley (4) suggested that the enhanced excretion of sodium following magnesium sulfate might be obligated by the excretion of the sulfate ion. However, chloride and sodium excretions were almost equimolar in the present study (and in his own averages), and the augmentation in their excretions was as great after magnesium acetate as that following magnesium sulfate.

The stimulation of sodium excretion might be attributed to osmotic diuresis, but against this interpretation is the fact that the sodium excretion fell abruptly when the serum magnesium concentration attained a plateau (as in Figure 6) and the excretions of magnesium and calcium were essentially constant. Also, Womersley (4) did not find significant increases in the rate of excretion of total osmols following the injection of $20 \mathrm{mEq}$. of magnesium as the sulfate salt. No explanation can be offered for the peculiar observation that the sodium and chloride excretions were enhanced only so long as the serum magnesium concentration was rising.

Heller, Hammarsten and Stutzman (3), with six subjects, and Womersley (4), with five, reported significant decreases in potassium excretion after magnesium sulfate injections. Pritchard (15) found no significant change in seven women with preeclampsia. Only 12 of our 28 patients had sustained decreases, while 6 had sustained increases in potassium excretion after injection of magnesium salts.

Unfortunately, the $\mathrm{pH}$ of the urines was not measured but if they were alkaline after the acetate injections, as seems probable, one would expect potassium excretion to be enhanced rather than decreased. Yet the potassium excretion was decreased in 27 of the 29 periods during magnesium acetate infusion (omitting the patient with nephritis). Berliner, Kennedy and Orloff (19) have reviewed the evidence for competition between hydrogen and potassium ions for exchange with sodium ions in the tubular lumen: When the urine is alkaline, hydrogen ion secretion is suppressed and potassium secretion is augmented.

\section{SUMMARY AND CONCLUSIONS}

Some effects of parenteral magnesium acetate and sulfate upon renal excretion of electrolytes were studied in 34 "normal" and abnormal women, selected to give a wide range of inulin clearances.

The magnesium clearance increased as a roughly linear function of the serum magnesium concentration; the attendant anion-acetate or sulfatehad little or no distinguishable effect upon the excretion of magnesium.

The ratio of magnesium clearance, corrected by nomogram for protein binding of serum magnesium, to inulin clearance approached 1 at the highest levels of serum magnesium studied. Roughly, this ratio was a linear function of the serum "filtrable" magnesium.

It appears that the tubular reabsorption of magnesium may be nearly maximal under "basal" conditions. Increments in the filtered load of magnesium, over "basal" levels, are excreted almost completely. This conclusion is tentative, for there is some uncertainty as to the validity of the calculations.

The injection of magnesium salts was followed by augmented urinary excretion of calcium. The increase in calcium excretion bore a direct relation to the serum magnesium concentration. 
Stimulation of sodium and chloride excretions was observed as long as the serum magnesium concentration was rising. When the serum magnesium became constant, or fell, the excretions of sodium and chloride dropped back toward, to, or below control levels.

The effect of magnesium upon potassium excretion varied from subject to subject.

\section{ACKNOWLEDGMENTS}

We wish to thank Dr. J. Leonard Brandt for valuable criticisms and Mrs. Pauline Fleetwood for technical assistance.

\section{REFERENCES}

1. Mendel, L. B., and Benedict, S. R. The paths of excretion for inorganic compounds. IV. The excretion of magnesium. Amer. J. Physiol. 1909, $25,1$.

2. Schwartz, B. M., Smith, P. K., and Winkler, A. W. Renal excretion of sulfate. Amer. J. Physiol. 1942, 137, 658.

3. Heller, B. I., Hammarsten, J. F., and Stutzman, F. L. Concerning the effects of magnesium sulfate on renal function, electrolyte excretion, and clearance of magnesium. J. clin. Invest. 1953, 32, 858.

4. Womersley, R. A. Studies on the renal excretion of magnesium and other electrolytes. Clin. Sci. 1956, 15, 465.

5. Jabir, F. K., Roberts, S. D., and Womersley, R. A. Studies on the renal excretion of magnesium. Clin. Sci. 1957, 16, 119.

6. Hammarsten, J. F., Allgood, M., and Smith, W. O. Effects of magnesium sulfate on renal function, electrolyte excretion and clearance of magnesium. J. appl. Physiol. 1957, 10, 476.

7. Barker, E. S., Clark, J. K., and Elkinton, J. R. Renal excretion of magnesium as influenced by lactate administration and certain other acute experimental conditions (abstract). Fed. Proc. 1955, $14,8$.

8. Barker, E. S., Clark, J. K., and Elkinton, J. R.
Renal response to magnesium loading in the dog (abstract). Fed. Proc. 1957, 16, 6.

9. Copeland, B. E., and Sunderman, F. W. Studies in serum electrolytes. XVIII. The magnesiumbinding property of the serum proteins. J. biol. Chem. 1952, 197, 331.

10. Willis, M. J., and Sunderman, F. W. Studies in serum electrolytes. XIX. Nomograms for calculating magnesium ion in serum and ultrafiltrates. J. biol. Chem. 1952, 197, 343.

11. Simonsen, D. G., Westover, L. M., and Wertman, M. The determination of serum magnesium by the molybdivanadate method for phosphate. J. biol. Chem. 1947, 169, 39.

12. Roe, J. H., Epstein, J. H., and Goldstein, N. P. A photometric method for the determination of inulin in plasma and urine. J. biol. Chem. 1949, 178, 839.

13. Peters, J. P., and Van Slyke, D. D. Quantitative Clinical Chemistry. Vol. II, Methods. Baltimore, Williams and Wilkins Co., 1932, pp. 764 and 833.

14. Etteldorf, J. N., Clayton, G. W., Tuttle, A. H., and Houck, C. R. Renal function studies in pediatrics. II. Influence of magnesium sulfate on renal hemodynamics in normal children. Amer. J. Dis. Child. 1952, 83, 301.

15. Pritchard, J. A. The use of the magnesium ion in the management of eclamptogenic toxemias. Surg. Gynec. Obstet. 1955, 100, 131.

16. Engbaek, L. The pharmacological actions of magnesium ions with particular reference to the neuromuscular and the cardiovascular system. Pharmacol. Rev. 1952, 4, 396.

17. Hopkins, T., Howard, J. E., and Eisenberg, H. U1trafiltration studies on calcium and phosphorus in human serum. Bull. Johns Hopk. Hosp. 1952, 91, 1.

18. Terepka, A. R., Toribara, T. Y., and Dewey, P. A. The ultrafiltrable calcium of human serum. II. Variations in disease states and under experimental conditions. J. clin. Invest. 1958, 37, 87.

19. Berliner, R. W., Kennedy, T. J., and Orloff, J. The relationship between potassium excretion and urine acidification in Ciba Foundation Symposium on the Kidney, A. A. C. Lewis and G. E. W. Wolstenholme, Eds. Boston, Little, Brown and Co., 1954 , pp. $147-158$. 